\title{
高配位ヶイ素化合物の特性と有機合成への応用
}

\author{
吉 良 満 夫* \\ Characteristics of Hypercoordinate Silicon Compounds and Their Application \\ to Organic Synthesis
}

Mitsuo KIRA*

\begin{abstract}
Preparation, characterization, and synthetic application of hypercoordinate organosilicon compounds are described. Regiospecific and highly diastereoselective allylation of aldehydes, aldimines, $\alpha$-hydroxy ketones, $\alpha$-ketocarboxylicacids, $\beta$-hydroxy-and $\beta$-amino- $\alpha, \beta$-enones, and 1,2 -diketones have been achieved by using pentacoordinate allylsilicates. Typically, reactions of stereohomogeneous $(E)$ - and $(Z)$-crotyltrifluorosilanes with various aldehydes in the presence of $\mathrm{CsF}$ or a wide variety of hydroxy compounds and triethylamine in THF gave the corresponding anti- and syn- $\beta$-methylhomoallyl alcohols, respectively, in highly diastereoselective manner. The stereoselectivity and the results of $a b$ initio MO calculations suggest that the present allylation proceeds via six-membered cyclic transition states including the coordination of carbonyl oxygen to the silicon of pregenerated pentacoordinate allylsilicates. Facile reduction of carbonyl compounds by using pentacoordinate hydridosilicates, structural characteristics of pentacoordinate silylsilicates, and oxidative $\mathrm{Si}-\mathrm{C}$ bond cleavage of, alkyl- and aryltrifluorosilanes by trimethylamine- $\mathrm{N}$-oxide are also described to present the unique feature of the organosilicates.
\end{abstract}

Key words : Hypercoordinate organosilicon compounds; Organic synthesis; Regiospecific allylation; Diastereoselective crotylation; Hydridosilicates; Silylsilicates; Oxidative $\mathrm{Si}-\mathrm{C}$ cleavage; Transition structure; $A b$ initio MO study.

1. はじめに

炭素の化学では $\mathrm{S}_{\mathrm{N}} 2$ 型求核置換反応の遷移状態に過ぎ ない 5 配位状態がケイ素では中間体や安定に単離できる 状態として存在する。それはケイ素の炭素と異なる際 だった特徴の 1 つである。ケイ素は 6 配位まで知られて おり，5配位ケイ素は 4 配位ケイ素の求核置換反応の中 間体であると同時に，さらに 6 配位ケイ素に至る中間体 でもある。言い換えると，5配位ケイ素上の配位子は 4 配位のときより高い脱離能を有するが，5配位ケイ素中 心にはさらに求核剤を受容して 6 配位になりうるルイス 酸性が残されている。このため，5配位ケイ素状態は独 特の反応場を形成することになる。

* 東北大学理学部

* Faculty of Science, Tohoku University

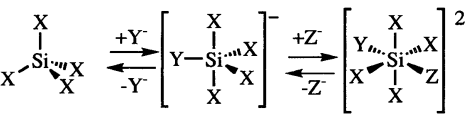

実際にはケイ素上の反応においても高配位状態は求核 置換反応の不安定中間体や遷移状態として仮定される存 在に過ぎない場合が多い。安定な形で単離されるものは むしろ少ない。単離できるほどに安定な高配位ケイ素化 合物を得るにはケイ素上の配位子としてフッ素やアルコ キシ基のような比較的小さい, 強い陰性基を導入する必 要がある。

近年, 6 配位アルキルシリカートを用いる有機合成が 玉尾, 熊田らによって展開されて以来, 高配位ヶイ素の 特性を生かした優れた有機合成反応が急速に開発される ようになった。高配位ケイ素の化学は大きな広がりをも つ研究領域に成長したと言える。

これまでに，この研究課題に関連する数多くの総説が 
出版されている ${ }^{1,2)}$ 。重複を避けて, 本稿では東北大学 のグループで行ったケイ素上にアリル，ヒドリド，シリ ル基等を有する 5 配位シリカートの合成, 構造, その有 機合成試剂としての応用に関する研究成果を中心に述べ る。

\section{2. アリルシリカート}

有機合成に用いられるさまざまな炭素一炭素結合生成 反応の中で，アリル金属試剤を用いるカルボニル化合物 やアセタールのアリル化反応は金属エノラートを用いる アルドール縮合と並んで応用の面からも, 反応機構の観 点からも重要な位置を占めている。アリルトリメチルシ ランを用いるアリル化反応は中でも重要であり, 四塩化 チタンなどのルイス酸存在下，ケトン，アセタール等の 種々の親電子試剤のアリル化が達成される ${ }^{3)}$ 。この反応 の推進力は $\mathrm{Si}-\mathrm{C} \sigma$ 結合とアリル $\pi$ 系との間の大きな $\sigma-\pi$ 共役であり,これによってアリル末端炭素の求核 性が高まり, 活性化されたカルボニル炭素と結合するこ とになると考えられている。

高配位ケイ素基もまたアリル $\pi$ 系に対して強い電子 供与基として作用することが予想され，以下に述べるよ うな位置特異性と高立体選択性をもつアリル化試剂とし て有用であることが発見された。関連する研究がほぼ同 時期に細見ら ${ }^{2 e, 4 a \sim c)}$ およびCorriu ら ${ }^{4 \mathrm{~d}}$ によって報告され ている。

なお，本稿で述べるアリルシランに対して以下のよう な化合物番号を用いた。
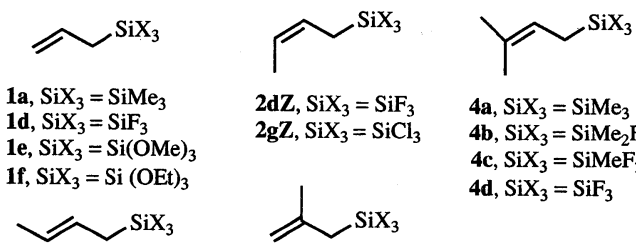

2dZ, $\mathrm{SiX}_{3}=\mathrm{SiF}_{3}$ $2 \mathrm{gZ}, \mathrm{SiX}_{3}=\mathrm{SiCl}_{3}$

4a, $\mathrm{SiX}_{3}=\mathrm{SiMe}_{3}$ 4b, $\mathrm{SiX}_{3}=\mathrm{SiMe}_{2} \mathrm{~F}$ 4c, $\mathrm{SiX}_{3}=\mathrm{SiMeF}_{2}$<smiles>[Y15]CC(=C)C</smiles>

4d, $\mathrm{SiX}_{3}=\mathrm{SiF}_{3}$

3d, $\mathrm{SiX}_{3}=\mathrm{SiF}_{3}$

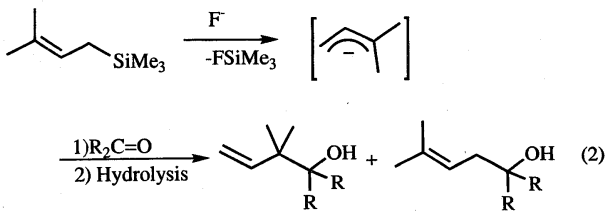

アリルアニオンを中間に生成する機構が妥当であると考 えられた5)。

しかし, Majetich らは $\mathrm{F}^{-}$によって促進される分子内 アリル化反応に対して，5配位シリカート中間体を保持 したままカルボニル炭素を攻撃するような機構を提唱し だ)。この 2 つの機構を区別する目的で，プレニルトリ メチルシランのケイ素上のメチル基を順次フッ素置換基 に置き換えた試剤 $(4 \mathrm{~b} \sim \mathrm{d})$ を用いてベンズアルデヒドの プレニル化の位置選択性を調べた7)。ケイ素上に嵩の小 さい電子吸引性の置換基を導入すると中間の 5 配位のシ リカートがより安定化されると期待された。反応の結果 を表 1 に示した。触媒量のフッ化テトラブチルアンモニ ウム $(\mathrm{TBAF})$ 存在下 $4 \mathrm{a}$ および $4 \mathrm{~b}$ を用いた反応では, 対応するホモアリルアルコールの位置異性体の混合物が 得られ，その比はほとんど同じであった。不思議なこと に，4c や $4 \mathrm{~d}$ を用いるとアリル化生成物は得られなかっ た。4cに対して 2 等量の $\mathrm{F}^{-}$を共存させてもほとんど 反応は進行しなかったが, $4 \mathrm{~d}$ は 2 等量の $\mathrm{F}^{-}$イオン存 在下ではきわめて速やかに反応が進行し，この際位置異 性体の一方のみが生成することが明らかになった。

Table 1 Reactions of various prenylsilanes with benzaldehyde.

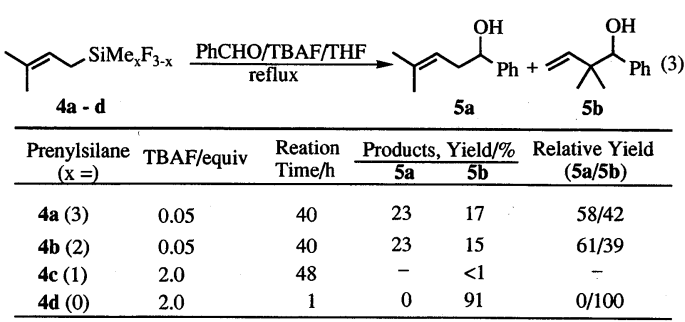

アリルトリフルオロシランはフッ化物イオンと安定な 5 配位シリカートを生成することが予想されたので，こ の反応は 5 配位アリルシリカートが直接カルボニル化合 物と反応したものと推定された。これが，5配位アリル シリカートを用いるアルデヒドの位置特異的, 高立体選 択的アリル化反応の発見の発端であった。一般に, アリ ルシランを用いるアルデヒドのアリル化はフッ化物イオ ンを用いると位置異性体の混合物を与え，ルイス酸を用 
いると副反応のため収率が低いが， $\mathrm{F}^{-}$源としてフッ化 セシウム $(\mathrm{CsF})$ を用いて，表 2 に示すようにきわめて高 収率で種々のアルデヒドの位置特異的プレニル化が達成 できだ)。

Table 2 Allylation of aldęhydes by using prenyltrifluorosilane in the presence of $\mathrm{CsF}$.

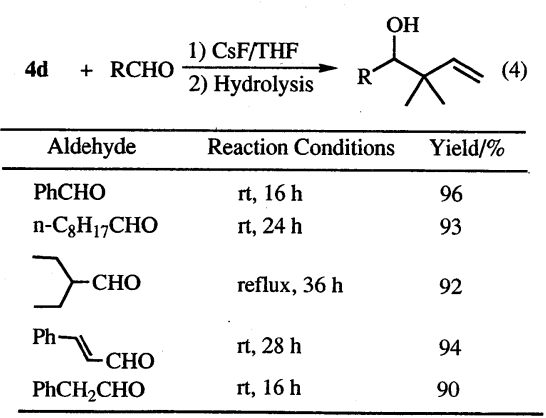

\subsection{5 配位アリルシリカートの単離とアリル化反応の} 高ジアステレオ選択性

上の例では中間のアリルシリカートの存在は確認され ていないが, 安定な 5 配位アリルシリカート類として以 下のようなシリカートが単離された。これらのシリカー トと芳香族アルデヒドとの反応を行うと，シリカート $6 \mathrm{a} \sim \mathrm{c}, 7,8 \mathrm{a} \sim \mathrm{c}$ では反応は遅いものの, 無触媒でア リル化反応が進行した (表 3$)^{99}$ 。

反応は高立体選択的に進行し， $7 \mathrm{E}$ 抢よび $7 \mathrm{Z}$ とベン ズアルデヒドとの反応では，きわめて高いジアステレオ 選択性で，それぞれ対応するホモアリルアルコールの anti およびsyn 体を生成した。立体選択性はクロチルボ ラートの反応の立体選択性 ${ }^{10)}$ と類似して扔り，下のよう な 6 員環状イス型遷移状態を経て進行することが示唆さ れた。すなわち，遷移状態ではアリルシランの $\gamma$-炭素

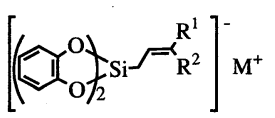

6a, $\mathrm{R}^{1}=\mathrm{R}^{2}=\mathrm{H}, \mathrm{M}=\mathrm{Li}$ 6b, $R^{1}=R^{2}=H, M=P P N$

7E, $\mathrm{R}^{1}=\mathrm{CH}_{3}, \mathrm{R}^{2}=\mathrm{H}, \mathrm{M}=\mathrm{Li}$ 7Z, $\mathrm{R}^{1}=\mathrm{H}, \mathrm{R}^{2}=\mathrm{CH}_{3}, \mathrm{M}=\mathrm{Li}$ 8a, $\mathrm{R}^{1}=\mathrm{R}^{2}=\mathrm{CH}_{3}, \mathrm{M}=\mathrm{Li}$ $\mathbf{8 b}, \mathbf{R}^{1}=\mathbf{R}^{2}=\mathrm{CH}_{3}, \mathbf{M}=\mathrm{PPN}$ $\mathrm{PPN}^{+}=\left[\mathrm{Ph}_{3} \mathrm{P}=\mathrm{N}=\mathrm{PPh}_{3}\right]^{+}$

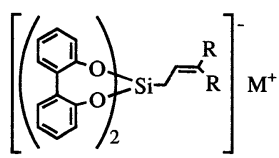

6c, $\mathrm{R}=\mathrm{H}, \mathrm{M}=\mathrm{Li}$ $8 c, \mathrm{R}=\mathrm{CH}_{3}, \mathrm{M}=\mathrm{Li}$

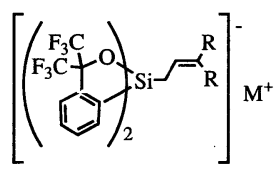

6d, $\mathrm{R}=\mathrm{H}, \mathrm{M}=\mathrm{Li}$ 6e, $\mathrm{R}=\mathrm{H}, \mathrm{M}=\mathrm{PPN}$ 8d, $\mathrm{R}=\mathrm{CH}_{3}, \mathrm{M}=\mathrm{Li}$ 8e, $\mathrm{R}=\mathrm{CH}_{3}, \mathrm{M}=\mathrm{PPN}$

Table 3 Allylation aromatic aldehydes by using pentacoordinate allylsilicates.<smiles>[R]/C(C)=C/C[As]C[3H]</smiles>

$6-8$

\begin{tabular}{cccc}
\hline Allylsilicate & $\begin{array}{c}\text { Aldehyde } \\
(\mathrm{Ar}=)\end{array}$ & Product & Yield/\% \\
\hline $\mathbf{6 a}$ & $\mathrm{Ph}$ & $\mathbf{9}$ & 91 \\
$\mathbf{6 a}$ & 2-Thienyl & $\mathbf{1 1}$ & 86 \\
$\mathbf{8 a}$ & $\mathrm{Ph}$ & $\mathbf{5 a}$ & 87 \\
$\mathbf{7 E} / \mathbf{7 Z}(88 / 12)$ & $\mathrm{Ph}$ & $\mathbf{1 0 A} / \mathbf{1 0 S}(88 / 12)$ & 82 \\
$\mathbf{7 E / 7 Z}(21 / 79)$ & $\mathrm{Ph}$ & $\mathbf{1 0 A} / \mathbf{1 0 S}(22 / 78)$ & 91 \\
$\mathbf{6 b}$ & $\mathrm{Ph}$ & $\mathbf{9}$ & 90 \\
$\mathbf{8 b}$ & $\mathrm{Ph}$ & $\mathbf{5 a}$ & 80 \\
$\mathbf{6 c}$ & $\mathrm{Ph}$ & $\mathbf{9}$ & 85 \\
$\mathbf{8 c}$ & $\mathrm{Ph}$ & $\mathbf{5 a}$ & 80 \\
\hline
\end{tabular}

がカルボニル炭素と結合を生成しつつあるが，同時にケ イ素はカルボニル酸素の配位を受けているとするもので ある。このとき，アルデヒドの $\mathrm{R}$ 基(フェニル基)がエ カトリアル位を占める配座が立体的に有利であるので， (E)-クロチルシリカートからはanti 体が, $(Z)$-体から は syn 体が高ジアステレオ選択的に生成したものと考え られる。一方，ヘキサフルオロクミルアルコールから導

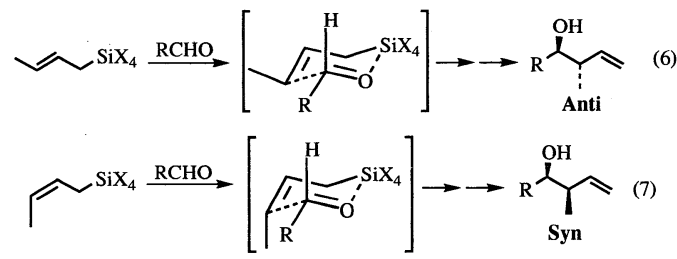
かれる 2 座配位子(Martin 配位子)を有する $6 \mathrm{~d}$, e p $8 \mathrm{~d}, \mathrm{e}$ では反応は全く進行しなかった。5 配位アリルシ リカート間の反応性の違いについては, 後にもう一度触 れる。

2.3. $(\boldsymbol{E})$ - および $(\boldsymbol{Z})$-クロチルトリフルオロシランを 用いるアルデヒドの高ジアステレオ選択的アリル 化反応

上述のことから， $(E)$ - および $(Z)$-クロチルトリフル オロシラン $(2 \mathrm{dE}$ と $2 \mathrm{dZ})$ をそれぞれ純粋に作ることが できるなら，フッ化物イオン存在下，アルデヒドとの反 応によって, 対応するホモアリルアルコールのジアステ レオマーを作り分けることができると期待される。 $2 \mathrm{dE}$ 
は高純度の $(E)$-塩化クロチルをトリエチルアミンと触 媒量の塩化銅 $(\mathrm{I})$ 存在下トリクロロシランと反応させ る $^{11 \mathrm{a})}$ ことよって $2 \mathrm{~g}$ の $(E)$-体を得た後, 三フッ化ア ンチモンを用いてフッ素化することによって合成でき た。また， $2 \mathrm{dZ}$ はトリクロロシランを用いて低温でブ タジエンのヒドロシリル化を行った後11b)，フッ素化す ることによって合成した。いずれも $99 \%$ 以上の純度で 合成することができるようになった。これらは保存可能 であるので，合成試剤としての価值が高い12)。

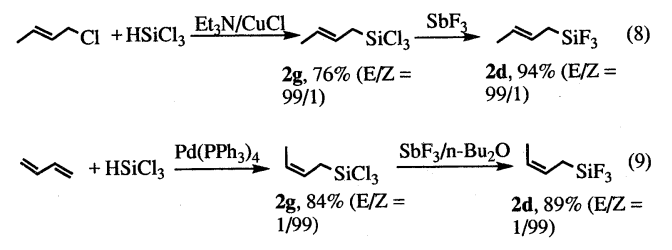

表 4 には, 種々のアルデヒドとの反応の結果を示した。 $2 \mathrm{dZ}$ と $2 \mathrm{dE}$ のいずれの場合でも, 生成物の収率とジア ステレオ選択はきわめて高い。2 $\mathrm{dZ}$ とかさ高い置換基を もつアルデヒドとの反応では若干立体選択性が悪いが,

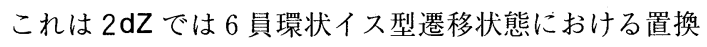
基間の立体反発がやや大きいためであろう。

Table 4 Diastereoselective addition of crotyltrifluorosilanes to aldehydes in the presence of $\mathrm{CsF}$.

\begin{tabular}{|c|c|c|c|c|}
\hline Aldehyde & 2d & Reaction Conditions & Yield/\% & Anti/Syn \\
\hline $\mathrm{PhCHO}$ & $\mathrm{E}$ & $0^{\circ} \mathrm{C}, 1 \mathrm{~h}$ & 92 & $99 / 1$ \\
\hline $\mathrm{n}-\mathrm{C}_{8} \mathrm{H}_{17} \mathrm{CHO}$ & $\mathrm{E}$ & $\mathrm{rt}, 4 \mathrm{~h}$ & 96 & $99 / 1$ \\
\hline$-\mathrm{CHO}$ & $\mathrm{E}$ & $\mathrm{rt}, 8 \mathrm{~h}$ & 68 & $99 / 1$ \\
\hline $\mathrm{CHO}$ & $\mathrm{E}$ & $\mathrm{rt}, 8 \mathrm{~h}$ & 77 & $98 / 2$ \\
\hline $\mathrm{PhMeCHCHO}$ & $\mathrm{E}$ & $0^{\circ} \mathrm{C}, 1.5 \mathrm{~h}$ & 91 & $99 / 1^{a}$ \\
\hline $\mathrm{PhCHO}$ & $\mathrm{Z}$ & $0^{\circ} \mathrm{C}, 1 \mathrm{~h}$ & 96 & $1 / 99$ \\
\hline $\mathrm{n}-\mathrm{C}_{8} \mathrm{H}_{17} \mathrm{CHO}$ & $\mathrm{Z}$ & $\mathrm{rt}, 5 \mathrm{~h}$ & 89 & $2 / 98$ \\
\hline$-\mathrm{CHO}$ & $\mathrm{Z}$ & $\mathrm{rt}, 12 \mathrm{~h}$ & 90 & $10 / 90$ \\
\hline $\mathrm{Ph} \searrow_{\mathrm{CHO}}$ & $\mathrm{Z}$ & $\mathrm{rt}, 14 \mathrm{~h}$ & 77 & $3 / 97$ \\
\hline PhMeCHCHO & $\mathrm{Z}$ & $\mathrm{rt}, 2 \mathrm{~h}$ & 92 & $10 / 90^{b}$ \\
\hline
\end{tabular}

2.4. アリルトリフルオロシラン/アルコール/トリエ チルアミン系を用いるアルデヒドのアリル化反応 アリルトリフルオロシランのトリフルオロシリル基は 電子吸引性が大きく, それ自体の反応性は低いが, 一方
で容易に高配位状態をとり得る特徵を持つ。種々のアル コール, ジオール, あるいは水(微量)とトリエチルアミ ンを共存させることにより, 高配位化が可能であり，ア ルデヒドの位置特異的, 高立体選択的アリル化を達成で

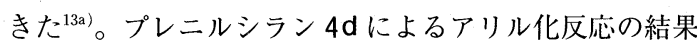
を表 5 に示した。興味深いことに, CsF 存在下の反応と は異なり， $2 \mathrm{~d}$ 抢よび $4 \mathrm{~d}$ と分岐アルデヒドとの反応は きわめて遅く, 直鎖アルデヒド(Nonanal) と分岐アルデ ヒド(2-Ethylhexanal)の 1:1 混合物のプレニル化では, ほとんど完全に, 直鎖アルデヒドのみがアリル化された。 $2 \mathrm{~d}$ の $(E)-$ および $(Z)-$ 体とアルデヒドの反応のジアス テレオの選択性は全く CsF 存在下の場合と同じであっ た。

Table 5 Allylation of aldehydes with prenyltrifluorosilane in the presence of a hydroxy compound and triethylamine.

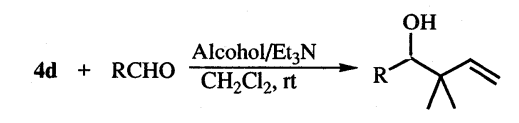

\begin{tabular}{|c|c|c|c|}
\hline Aldehyde & $\begin{array}{l}\text { Hydroxylic } \\
\text { Compound }\end{array}$ & $\begin{array}{l}\text { Reaction } \\
\text { Time/h }\end{array}$ & Yiled $/ \%$ \\
\hline \multirow[t]{8}{*}{$\mathrm{PhCHO}$} & Catechol & 20 & 93 \\
\hline & $\begin{array}{l}\text { 2,2'-Dihydroxy } \\
\text { Biphenyl }\end{array}$ & 48 & 88 \\
\hline & $\mathrm{PhCH}(\mathrm{OH}) \mathrm{COOH}$ & 24 & 83 \\
\hline & $(\mathrm{COOH})_{2}$ & 24 & 90 \\
\hline & & 15 & 72 \\
\hline & $\mathrm{NH}_{2}\left(\mathrm{CH}_{2}\right)_{2} \mathrm{OH}$ & 30 & 45 \\
\hline & $\mathrm{MeOH}$ & 48 & 83 \\
\hline & $\mathrm{H}_{2} \mathrm{O}$ & & \\
\hline $\mathrm{Ph}\left(\mathrm{CH}_{2}\right)_{2} \mathrm{CHO}$ & Catechol & 20 & 82 \\
\hline $\mathrm{CH}_{3}\left(\mathrm{CH}_{2}\right)_{7} \mathrm{CHO}$ & Catechol & 20 & 87 \\
\hline
\end{tabular}

最近，アリルトリクロロシランのアリルトリフルオロ シランへの変換と引き続くアルデヒドのアリル化を一容 器内で行い得ることがわかった ${ }^{13 b)}$ 。すなわち, THF 中 アリルトリクロロシランを $2 \sim 3$ モルのフッ素化郕 $\left(\mathrm{SbF}_{3}\right.$ またはアンモニウムへキサフルオロシリカート) と混合し, 30 分から 1 時間反応させた後, カテコール とトリエチルアミンを $0{ }^{\circ} \mathrm{C} て ゙$ 加えて 10 分間攪找し, ア ルデヒドを加えてさらに 20 時間攪拌する方法である。 また, 最近小林らによって, アリルトリクロロシランを DMF 中で用いるアルデヒドの高立体選択的アリル化反 応が報告された ${ }^{14)}$ 。この方法は, 反応温度も低く, 時間 も短かく, 合成化学的にさらに優れた方法といえよう。 


\subsection{5 配位アリルシリカートの電子状態とアルデヒド との反応の遷移状態の理論的考察}

5 配位シリカートの高い反応性とアルデヒドとの反応 において，6員環状遷移状態をとる理由は定性的に以下 のように理解される ${ }^{9,15)}$ 。すなわち, アリルトリメチル シランの $\gamma$ 位炭素の高い求核反応性はアリル $\pi$ 軌道と 炭素-ケイ素 $\sigma$ 軌道間の $\sigma-\pi$ 共役によるものと考えられ るが，4配位アリルシランのケイ素上にフッ素や酸素の ような電気陰性度の大きな原子が置換するとその $\sigma-\pi$ 共役の程度は低下し, 求核反応性は低くなると考えられ る。しかし，5配位シリカートになると，このケイ素基 はアリル $\pi$ 系に対して再び強い電子供与性基として作 用して, アリル $\gamma$-炭素の求核性は増加する。5 配位ア リルシリカートはさらに 6 配位になりうるルイス酸性が ある。ケイ素上 6 配位になれば，アリル $\gamma$-炭素はさら に高い求核反応性を獲得できることになるので，5配位 アリルシリカートはアルデヒドとの反応の遷移状態にお いてカルボニル酸素の配位を受けて 6 配位をとりつつ $\mathrm{C}-\mathrm{C}$ 結合生成するような 6 員環状遷移状態をとるのが 有利であると推定される(図 1)。

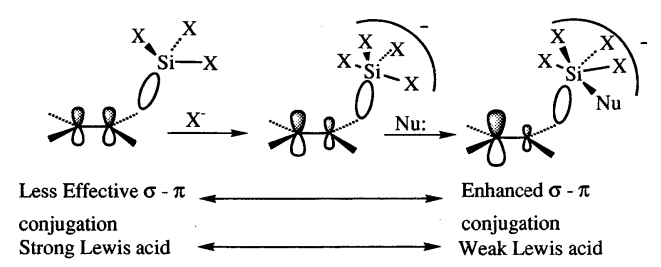

Fig. 1 Schematic presentation of the effects of hypercoordination on the HOMO of allylsilanes and the Lewis acidity.

一連のアリルケイ素化合物 $\left(\left[\mathrm{CH}_{2}=\mathrm{CHCH}_{2} \mathrm{SiF}_{n}\right]^{3-n} ; 1 \mathrm{~d}\right.$, $n=3 ; 12, n=4 ; 13, n=5)$ の電子状態を明らかにし， そのアリル $\gamma$ 炭素の求核性とケイ素ルイス酸性の程度 を知ること，および 12 とホルムアルデヒドとの反応(式 13)の最も有利な遷移構造 (TS)を見いだすことを目的と
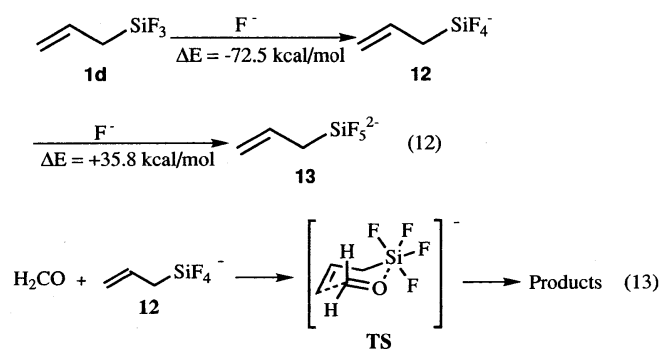

して非経験的分子軌道計算を行った ${ }^{16)}$ 。

アリルケイ素化合物, $1 \mathrm{~d}, 12$, および 13, ホルムア ルデヒドおよび生成物の構造は MIDI-4 基底セットを用 いて最適化した $(\mathrm{C}, \mathrm{O}$ ，および $\mathrm{Si} に は \mathrm{~d}$ 関数を，Fには アニオン $\mathrm{p}$ 関数を含めた)。遷移構造は MIDI-4(*)基底 セット(標準 MIDI-4+Si d 軌道)を用いて決定した。 $\gamma$ 炭素の電子密度は $1 \mathrm{~d}, 12,13$ の順に増加し，高配位に なるに従って $\gamma$ 炭素の求核性の増加することが示され た(表 6)。また，これらのケイ素上の電荷は正であり， 高配位になるほどその正電荷はむしろ増加した。1 d と 12 のケイ素上の正電荷はほぼ同程度であり，5配位ケイ 素中心は，立体的には不利であるものの，ある程度のル イス酸性を有するとの考えを支持した。

Table 6 Mulliken charges for allylsilicates calculated with MIDI-4* basis sets.

\begin{tabular}{ccccc}
\hline \multirow{2}{*}{ Compound } & \multicolumn{4}{c}{ Mulliken Charge } \\
\cline { 2 - 5 } & $\alpha-\mathrm{C}$ & $\beta-\mathrm{C}$ & $\gamma-\mathrm{C}$ & $\mathrm{Si}$ \\
\hline $\mathbf{1 d}$ & -0.40 & -0.25 & -0.26 & 1.37 \\
$\mathbf{1 2}$ & -0.37 & -0.22 & -0.31 & 1.38 \\
$\mathbf{1 3}$ & -0.38 & -0.11 & -0.38 & 1.51 \\
\hline
\end{tabular}

MIDI-4(*)基底セットを用いて直鎖状，6員環状イス 型および 3 種の舟型遷移状態構造を決定することを試み た。このうち，直鎖状抢よび 6 員環状イス型の遷移構造 を決定できたが，舟型遷移構造は見つけられていない。 イス型構造は直鎖状のものより $50.2 \mathrm{kcal} / \mathrm{mol}$ 低エネル ギーであった。決定された鎖状およびイス型遷移構造を 図 2 に示す。イス型遷移構造において, 生成しつつある $\mathrm{C}_{4} \cdots \mathrm{C}_{5}$ 間距離は $2.22 \AA$ であり，アリルボランおよびア リルボロン酸とホルムアルデヒドとの反応について 3$21 \mathrm{G}$ 基底セットを用いて計算された值(それぞれ，2.28 および $2.18 \AA)^{17)}$ とよく一致している。これらの反応の 環状遷移状態において $\mathrm{C}_{3}-\mathrm{C}_{4}$ 間距離は $\mathrm{C}_{2}-\mathrm{C}_{3}$ 間よりも短 かく，いわゆる早い遷移状態(early transition state)を 経由する反応であることがわかる。

このイス型遷移構造において，ホルムアルデヒドの水 素の 1 つをメチル基で置き換えると，メチル基がアキ シャル位にある方がエカトリアル位を占める場合より も, $18.7 \mathrm{kcal} / \mathrm{mol}$ 不安定であった。アリルボランとア ルデヒドの反応ではこの差が $5.5 \mathrm{kcal} / \mathrm{mol}(3-21 \mathrm{G})$ であ るので ${ }^{17)}$ ，アリルシリカートの反応の方が高い立体選択 性を示すことが示唆される。これらの結果は定性的に実 験事実と一致する。以上のように，ケイ素ルイス酸中 心一求核剂複合系の反応における高配位ケイ素の役割が 理論計算によってより明確になった。 

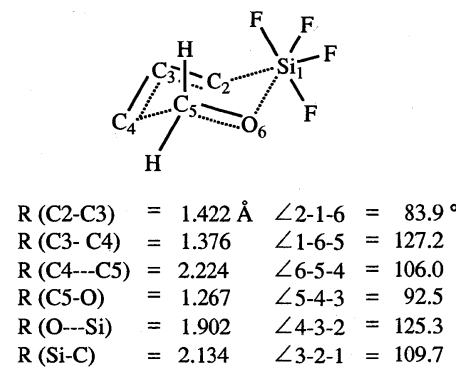

Chair TS<smiles>O=CC=[Si]=C[Si](F)(F)F</smiles>

$\mathrm{R}(\mathrm{C} 2-\mathrm{C} 3)=1.351 \AA \quad \angle 3-4-5-6=-175.6^{\circ}$

$\mathrm{R}(\mathrm{C} 3-\mathrm{C} 4)=1.481$

$\mathrm{R}(\mathrm{C} 4--\mathrm{C} 5)=1.616$

$R(C 5-O)=1.340$

$\mathrm{R}(\mathrm{Si}-\mathrm{C}) \quad=2.783$

\section{Linear TS}

Fig. 2 Structures of transition state for the reaction of 12 with $\mathrm{H}_{2} \mathrm{CO}$ determined with MIDI-4(*) basis set.

2.6. 5 配位アリルシリカートのルイス酸性とアリル化 の反応性に及ぼすケイ素上置換基の効果

上で述べた種々の 5 配位アリルシリカートはアルデヒ ドとの反応の位置特異性とジアステレオ選択性の点では 共通しているが，反応性と基質選択性にはかなりの違い がみられる12)。すなわち，アリルトリフルオロシラン／ $\mathrm{CsF}$ 系では芳香族, 脂肪族アルデヒドを問わず広範囲の アルデヒドをアリル化できるが，アリルトリフルオロシ ランノアルコール／アミン系では脂肪族分岐アルデヒド は反応しない。カテコラートやジフェノラートの配位し た安定シリカートは芳香族アルデヒドとのみ反応する。 Martin 配位子を有する $6 \mathrm{~d}, \mathrm{e} や 8 \mathrm{~d}, \mathrm{e}$ は芳香族アルデヒ ドとも反応しなかった。この反応性のスペクトルはアリ ルシリカートのルイス酸性に対するケイ素上置換基の電 子立体的効果を反映したものとみられる。
2.7. $\alpha$-ヒドロキシケトンおよび関連化合物のアリル 化反応

5 配位アリルシリカートはアセトフェノン等の通常の ケトンとは全く反応しない。しかし，アリルトリフルオ ロシランとトリエチルアミンの組み合わせを用いて, 種々の $\alpha$-ヒドロキシケトンの高立体選択的アリル化を 行うことができた $(\text { 表 7 })^{18)}$ 。

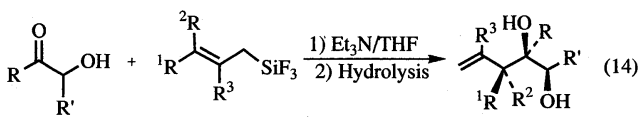

この際，水酸基の付け根の炭素がキラルであるベンゾ インの場合には生成物の 2 つ水酸基の立体化学が syn の関係にあるもの (1,2-syn 体)のみが生成する。クロチ ルシラン $2 \mathrm{dE}$ および $2 \mathrm{dZ}$ を用いると 3 つの炭素の立体 化学を同時に制御でき， $2 \mathrm{dE}$ から 1,2-syn かつ 2,3-syn 体を，2dZからは1,2-syn かつ 2,3-anti-体をほぼ完全 に生成する。また，3-ヒドロキシ-2-ブタノン(15)では その 1,2-syn/anti 選択性はアリル基上の置換基によって 大きな影響を受ける。1dではその比は $66 / 34$ であるが， 3dでは $92 / 8$ まで向上する。これらのことを考え合わせ るとこの反応では下に示すように, 水酸基の酸素とカル ボニル酸素が共にケイ素上に配位した 2 環式遷移状態を 経由することが示唆される。

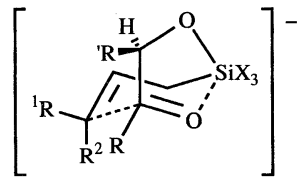

TS
この方法は $\alpha$-ケトンカルボン酸にも適用でき, 表 8 に示すように, 高収率かつ高立体選択的にアリル化生成 物が得られる。

アリルトリフルオロラン/トリエチルアミン系は一般 の $\beta$ - 怙よび $\gamma$-ヒドロキシケトンとは反応しないが, 表 9 および 10 に示すように, $\beta$-ヒドロキシエノン $\left(1,3^{-}\right.$

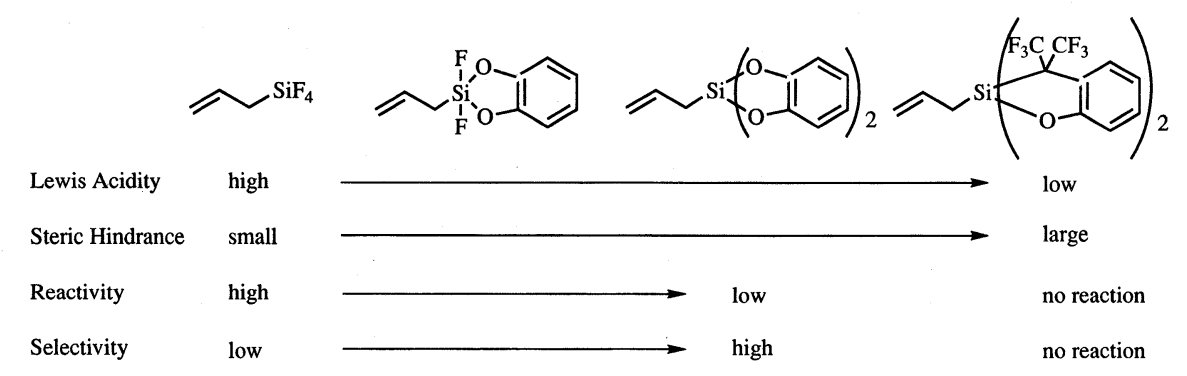


Table 7 Reactions of allyltrifluorosilanes and allyltrialkoxysilanes with $\alpha$-hydroxy ketones in the presence of triethylamine in THF.

\begin{tabular}{|c|c|c|c|c|}
\hline Allylsilane & Ketone & Reaction Conditions & Major Product & Yield $/ \%$, \\
\hline 4d & & reflux, $20 \mathrm{~h}$ & & 71 \\
\hline $2 \mathrm{dE}$ & 14 & $\mathrm{rt}, 15 \mathrm{~h}$ & & $\begin{array}{c}83 \\
(97 / 3)\end{array}$ \\
\hline $2 \mathrm{dZ}$ & 14 & $\mathrm{rt}, 14 \mathrm{~h}$ & & $\begin{array}{c}87 \\
(5 / 95)\end{array}$ \\
\hline $2 \mathrm{dE}$ & & reflux, $20 \mathrm{~h}$ & & 72 \\
\hline $2 \mathbf{d E}$ & & reflux, $40 \mathrm{~h}$ & & $\begin{array}{c}74 \\
(97 / 3)\end{array}$ \\
\hline 1d & 15 & reflux, $40 \mathrm{~h}$ & & $\begin{array}{c}69 \\
\{66 / 34\}\end{array}$ \\
\hline 3d & 15 & reflux, $48 \mathrm{~h}$ & & $\begin{array}{c}45 \\
\{92 / 8\}\end{array}$ \\
\hline $2 \mathrm{dE}$ & & $\begin{array}{l}\mathrm{H} \text { reflux, 30h } \\
\text { (16) }\end{array}$ & & $\begin{array}{c}71 \\
(93 / 7) \\
\{100 / 0\}\end{array}$ \\
\hline $2 \mathrm{dZ}$ & 16 & reflux, $30 \mathrm{~h}$ & & $\begin{array}{c}75 \\
(5 / 95)\end{array}$ \\
\hline 1d & 16 & reflux, $30 \mathrm{~h}$ & & $\begin{array}{c}68 \\
\{100 / 0\}\end{array}$ \\
\hline 1e & 16 & reflux, $60 \mathrm{~h}$ & & $\begin{array}{c}60 \\
\{100 / 0\}\end{array}$ \\
\hline If & 16 & reflux, $72 \mathrm{~h}$ & & 54 \\
\hline
\end{tabular}

a. 2,3-Syn/anti ratio is shown in parentheses. b. 1,2-Syn/anti ratio is shown in braces.

ジケトンのエノール体)および $\beta$-アミノエノン型化合物 はアリル化生成物を与える ${ }^{19)}$ 。上に述べた 2 環式遷移状 態を比較的容易にとることができるためであろう。

表 11 に示したように，1,2-ジケトンをアリルトリフ ルオロシラン $(1.5$ モル $)$ とトリエチルアミン (1.5 モル $)$ 存在下で反応させるとモノアリル化生成物が得られる。 この際，非対称ジケトンを用いると，エノール化しやす いアルキル基に結合したカルボニル基がまずアリル化さ れる。大過剩のアリルトリフルオロシラン/トリエチル アミン系を用いると 2 重アリル化できる(表 12) ${ }^{13 \mathrm{~b})}$ 。

また，やや過激な条件を必要とするが，アリルトリフ ルオロシラン $/ \mathrm{CsF}$ 系はアルジミンとも反応してアリル 化生成物を与えた。表 13 にクロチルトリフルオロシラ
Table 8 Reactions of allyltrifluorosilanes and allyltrialkoxysilanes with $\alpha$-ketocarboxylic acids in the presence of triethylamine in THF.

\begin{tabular}{|c|c|c|c|c|}
\hline Allylsilane & $\begin{array}{c}\text { Ketocarboxylic } \\
\text { Acid }\end{array}$ & $\begin{array}{l}\text { Reaction } \\
\text { Conditions }\end{array}$ & Major Product & Yield $/ \%^{\mathrm{a}}$ \\
\hline $\begin{array}{l}2 d(E / Z \\
=97 / 3)\end{array}$ & & $\mathrm{rt}, 12 \mathrm{~h}$ & & $\begin{array}{c}94 \\
(97 / 3)\end{array}$ \\
\hline $\begin{array}{l}2 d(E / Z \\
=5 / 95)\end{array}$ & $\mathrm{COOH}$ & $\mathrm{rt}, 12 \mathrm{~h}$ & & $\begin{array}{c}96 \\
(4 / 96)\end{array}$ \\
\hline 1d & & $\mathrm{rt}, 18 \mathrm{~h}$ & & 94 \\
\hline 1d & $\mathrm{OH}$ & $\mathrm{rt}, 18 \mathrm{~h}$ & & 95 \\
\hline 1e & & reflux, $30 \mathrm{~h}$ & & 31 \\
\hline
\end{tabular}

a. Syn/anti ratio is shown in parentheses.

Table 9 Allylation of 0 -hydroxy-and $o$-aminoacetopheneone with allyltrifluorosilanes in the presence of triethylamine.

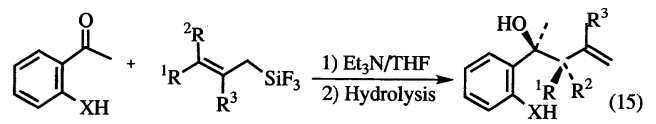

\begin{tabular}{ccll}
\hline $\begin{array}{c}\text { Acetophenone } \\
(\mathrm{X}=)\end{array}$ & Allylsilane & Reaction Conditions & Yield/\% \\
\hline $\mathrm{O}$ & 2d $(\mathrm{E} / \mathrm{Z}=97 / 3)$ & rt, $48 \mathrm{~h}$ & 90 \\
$\mathrm{O}$ & 2d $(\mathrm{E} / \mathrm{Z}=5 / 95)$ & rt, $48 \mathrm{~h}$ & 83 \\
$\mathrm{O}$ & 3d & rt, $48 \mathrm{~h}$ & 90 \\
$\mathrm{O}$ & 4d & reflux, 36 h & 90 \\
$\mathrm{NH}$ & 1d & reflux, 40 h & 63 \\
$\mathrm{NH}$ & 2d $(\mathrm{E} / \mathrm{Z}=88 / 12)$ & reflux, 40 h & $68(92 / 8)^{\mathrm{a}}$ \\
$\mathrm{NH}$ & 3d & reflux, 29 h & 65 \\
\hline
\end{tabular}

Table 10 Allylation of 1,3-diketones with allyltrifluorosilanes in the presence of triethylamine.

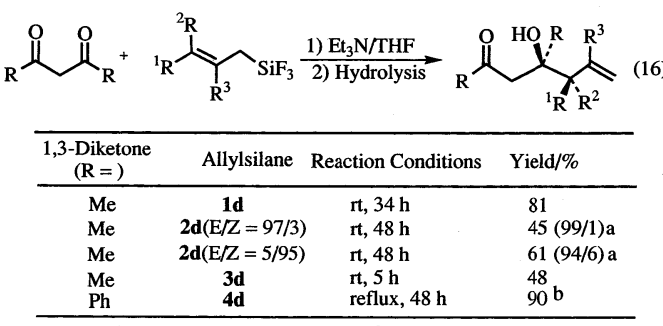

a. Syn/anti ratio. b. Isolated as an $\alpha, \beta$-unsaturated ketone.

ン $2 \mathrm{dE}$ および $2 \mathrm{dZ}$ と種々のアルジミンの反応の結果を 示した。反応のジアステレオ選択性は必ずしもよくな く, この反応では 6 員環ボート型遷移状態を経由する反 応も混在する可能性が示唆された ${ }^{20)}$ 。 
Table 11 Allylation of 1,2-diketones with allyltrifluorosilanes in the presence of triethylamine.

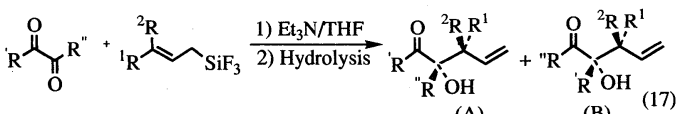

(A)

(B) (17)

\begin{tabular}{|c|c|c|c|c|c|}
\hline \multicolumn{2}{|c|}{ 1,2-Diketone } & \multirow{2}{*}{ Allylsilane } & \multirow{2}{*}{$\begin{array}{l}\text { Reaction } \\
\text { Conditions }\end{array}$} & \multirow{2}{*}{ Yield $/ \%^{\mathrm{a}}$} & \multirow{2}{*}{$\mathrm{A} / \mathrm{B}$} \\
\hline $\mathbf{R}^{\prime}$ & $\mathrm{R}^{\prime \prime}$ & & & & \\
\hline $\mathrm{Me}$ & $\mathrm{Me}$ & $2 d(E / Z=88 / 12)$ & $\mathrm{rt}, 40 \mathrm{~h}$ & $67(88 / 12)$ & \\
\hline $\mathrm{Me}$ & $\mathrm{Me}$ & $2 d(E / Z=3 / 97)$ & $\mathrm{rt}, 40 \mathrm{~h}$ & $69(4 / 96)$ & \\
\hline \multirow[t]{2}{*}{$\mathrm{Me}$} & $\mathrm{Me}$ & 4d & reflux, $40 \mathrm{~h}$ & 58 & \\
\hline & $\begin{array}{l}14^{b} \\
14\end{array}$ & $\begin{array}{c}\text { 2d }(E / Z=88 / 12) \\
2 d(E / Z=3 / 97) \\
\text { 4d }\end{array}$ & $\begin{array}{l}\mathrm{rt}, 40 \mathrm{~h} \\
\mathrm{rt}, 40 \mathrm{~h} \\
\text { reflux, } 40 \mathrm{~h}\end{array}$ & $\begin{array}{l}74(86 / 14) \\
75(2 / 98) \\
81\end{array}$ & \\
\hline $\mathrm{Me}$ & $\mathrm{Et}$ & $2 d(E / Z=88 / 12)$ & $\mathrm{rt}, 40 \mathrm{~h}$ & $65(90 / 10)$ & $100 / 0$ \\
\hline $\mathrm{Me}$ & Et & $2 d(E / Z=3 / 97)$ & $\mathrm{rt}, 40 \mathrm{~h}$ & \multirow{2}{*}{$\begin{array}{l}67(4 / 96) \\
68\end{array}$} & $100 / 0$ \\
\hline $\mathrm{Me}$ & Et & $4 d$ & reflux, $40 \mathrm{~h}$ & & $100 / 0$ \\
\hline $\mathrm{Me}$ & $\mathrm{Ph}$ & $2 d(E / Z=88 / 12)$ & $\mathrm{rt}, 40 \mathrm{~h}$ & $69(89 / 11)$ & $3 / 97$ \\
\hline $\mathrm{Me}$ & $\mathrm{Ph}$ & $2 d(E / Z=3 / 97)$ & $\mathrm{rt}, 40 \mathrm{~h}$ & $65(3 / 97)$ & $2 / 98$ \\
\hline \multirow[t]{2}{*}{$\mathrm{Me}$} & $\mathrm{Ph}$ & $4 d$ & reflux, $40 \mathrm{~h}$ & 75 & $71 / 29$ \\
\hline & & $4 d$ & reflux, $40 \mathrm{~h}$ & 68 & $100 / 0$ \\
\hline
\end{tabular}

Table 12 Double allylation of 1,2-diketones with allyltrifluorosilanes in the presence of triethylamine.

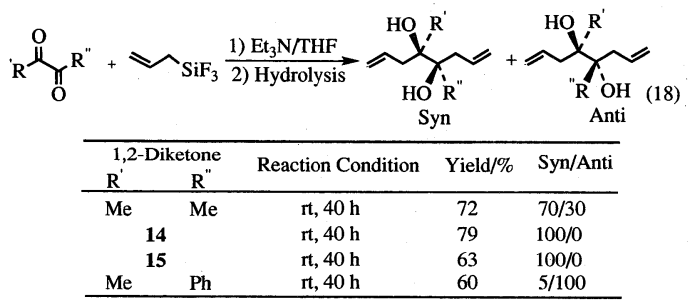

Table 13 Allylation of aldimines with crotyltrifluorosilanes in the presence of $\mathrm{CsF}$.

\begin{tabular}{clcc} 
& & & \\
\hline Allylsilane & Aldimine & Yield/\% & Syn/Anti \\
\hline $\mathbf{2 d E}$ & $\mathrm{PhCH}=\mathrm{NPh}$ & 94 & $71 / 29$ \\
$\mathbf{2 d E}$ & $\mathrm{PhCH}=\mathrm{NCH}_{2} \mathrm{Ph}$ & 91 & $73 / 27$ \\
$\mathbf{2 d E}$ & $\mathrm{PhCH}=\mathrm{NPr}$ & 81 & $71 / 29$ \\
$\mathbf{2 d E}$ & $\mathrm{n}-\mathrm{PrCH}=\mathrm{NPr}-\mathrm{n}$ & 20 & $71 / 29$ \\
$\mathbf{2 d E}$ & i-PrCH=NPr-n & 67 & $77 / 23$ \\
$\mathbf{2 d Z}$ & $\mathrm{PhCH}=\mathrm{NPh}$ & 91 & $40 / 60$ \\
$\mathbf{2 d Z}$ & $\mathrm{PhCH}=\mathrm{NCH}{ }_{2} \mathrm{Ph}$ & 85 & $28 / 72$ \\
$\mathbf{2 d Z}$ & $\mathrm{PhCH}=\mathrm{NPr}$ & 75 & $28 / 72$ \\
$\mathbf{2 d Z}$ & n-PrCH=NPr-n & 20 & $42 / 58$ \\
$\mathbf{2 d Z}$ & i-PrCH=NPr-n & 66 & $57 / 43$ \\
\hline
\end{tabular}

\section{3. ヒドリドシリカート}

種々のヒドロシランを $\mathrm{F}^{-}$とともに用いてカルボニル 化合物を還元できることはよく知られている ${ }^{21 ~ 23) 。 こ の ~}$

反応の活性種はヒドロシランと $\mathrm{F}^{-}$の反応によって生成 する 5 配位ケイ素種であると考えられる。ヒドロシラン のケイ素に結合した水素のヒドリド性が高配位状態にな ることによって高められた結果であると考えられる。実 際, 表 14 に示すように, THF 中ジリリウムカテコラー トとトリクロロシランとの反応によって生成する 5 配位 ヒドリドシリカート(16)や類似のヒドリドシリカート 17, 18 を用いて, 種々のカルボニル化合物の対応するア ルコールへの還元が行える24,25)。

以前にMartin らは 5 配位ヒドリドシリカート 18 を安 定に単離したことを報告したが26a)，実際には18 は室温 では不安定であり, $\mathrm{PPN}^{+}$を対カチオンとして用いるこ とによってはじめて安定な 5 配位ヒドリドシリカート 19 を単離できた(後に Martin らは別法を用いることに より 18 が安定な化合物として単離できることを報告し ている $)^{26 b)}$ 。19を用いて実際にカルボニル化合物の還元 を行うことができる。

Table 14 Reduction of carbonyl compounds with bis (diolato)hydridosilicates.

\begin{tabular}{|c|c|c|c|}
\hline Silicate & $\begin{array}{l}\text { Carbonyl } \\
\text { Compound }\end{array}$ & $\begin{array}{l}\text { Reaction } \\
\text { Conditions }\end{array}$ & Yield/\% \\
\hline 16 & $\mathrm{PhCHO}$ & $0^{\circ} \mathrm{C}, 2 \mathrm{~h}$ & 96 \\
\hline 16 & 4-Me-PhCHO & $0^{\circ} \mathrm{C}, 2 \mathrm{~h}$ & 96 \\
\hline 16 & $\mathrm{PhMeC}=\mathrm{O}$ & $0^{\circ} \mathrm{C}, 2 \mathrm{~h}$ & 98 \\
\hline 16 & Cyclohexanone & $0^{\circ} \mathrm{C}, 2 \mathrm{~h}$ & 95 \\
\hline 16 & 4-t-Butylcyclohexanone & $0^{\circ} \mathrm{C}, 2 \mathrm{~h}$ & $92(E / Z=56 / 44)$ \\
\hline 16 & $\mathrm{PhCOOMe}$ & $\mathrm{rt}, 12 \mathrm{~h}$ & 0 \\
\hline 17 & 4-t-Butylcyclohexanone & $\mathrm{rt}, 5 \mathrm{~h}$ & $92(\mathrm{E} / \mathrm{Z}=33 / 67)$ \\
\hline $\mathbf{1 7}$ & $\mathrm{CH}_{3} \mathrm{CO}\left(\mathrm{CH}_{2}\right)_{4} \mathrm{CH}_{3}$ & $\mathrm{rt}, 5 \mathrm{~h}$ & 90 \\
\hline 17 & $\mathrm{t}-\mathrm{BuCHO}$ & $\mathrm{rt}, 5 \mathrm{~h}$ & 92 \\
\hline 17 & i-PrCOPr-i & $\mathrm{rt}, 30 \mathrm{~h}$ & 50 \\
\hline 17 & $\mathrm{PhMeC}=\mathrm{O}$ & $\mathrm{rt}, 5 \mathrm{~h}$ & 97 \\
\hline 18 & Cyclohexanone & $0^{\circ} \mathrm{C}, 2 \mathrm{~h}$ & 80 \\
\hline 18 & $\mathrm{PhCHO}$ & $0^{\circ} \mathrm{C}, 2 \mathrm{~h}$ & 95 \\
\hline 18 & $\mathrm{PhMeC}=\mathrm{O}$ & $0^{\circ} \mathrm{C}, 2 \mathrm{~h}$ & 88 \\
\hline 18 & $\mathrm{CH}_{3}\left(\mathrm{CH}_{2}\right)_{7} \mathrm{CHO}$ & $0^{\circ} \mathrm{C}, 2 \mathrm{~h}$ & 81 \\
\hline 19 & $\mathrm{PhCHO}$ & $0^{\circ} \mathrm{C}, 2 \mathrm{~h}$ & 69 \\
\hline
\end{tabular}
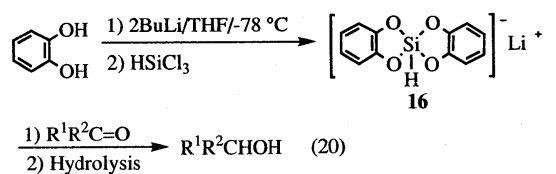

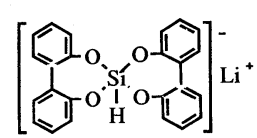

17

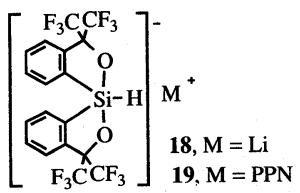

式(19)で置換ベンズアルデヒドを用いたときの反応の 相対速度の対数は Hammett $の$ 置換基定数 $\sigma$ と直線関係 を示した $(\rho=2.3, r=0.999)$ 。律速過程でヒドリド移 
動が重要であることを示している。4- $t$-ブチルシクロ ヘキサノンの種々の金属水素化物による還元はかさ高い 置換基を導入すると $Z$-体を優先するようになることは よく知られている。ヒドリドシリカートによる還元にお いてもそのような傾向がみられ，16では $E / Z$ 比が 56/44であったものがかさ高い 17 を用いると 33/67 ま で変化した。

\section{4. シリルシリカート}

ジシランの $\mathrm{Si}-\mathrm{Si}$ 結合の金属アルコキシドや $\mathrm{F}^{-}$によ る切断反応はよく知られており, シリルアニオンの生成 法として用いられている ${ }^{28)}$ 。この時，暗に 5 配位ケイ素 中間体を経由すると仮定されることが多い。シリルシリ カートは 5 配位ケイ素と 4 配位ケイ素の直接結合を含 み，その構造と反応性に興味が持たれる。しかし， Gordon の $a b$ initio MO 計算の結果によると ${ }^{29)} ， 5$ 配位シリ ルシリカート種が安定な化学種として存在することは疑 問視された。

これまでの高配位ケイ素化合物研究の成果をもとに, 以下のような, シリルシリカートを安定に単離すること ができた ${ }^{30)}$ 。また, 化合物 20bについては結晶の X 線 構造解析に成功した。その $\mathrm{Si}-\mathrm{Si}$ 結合距離は $2.40 \AA$ と 通常の 4 配位ケイ素間のものとあまり変わらないが, 20 b は Martin 配位子を有する 5 配位ケイ素化合物の中 で理想的な 3 方両錐構造に最も近い構造を有するなど, いくつかの特徵が観察された。また，4配位フェニルジ シランは 230 ～ $240 \mathrm{~nm}$ 付近に吸収を示すが, 20a,bは いずれも, さらに長波長の $250 \mathrm{~nm}$ 付近に強い UV 吸収 を示した。また, ${ }^{29} \mathrm{Si}^{-29} \mathrm{Si}$ 結合定数は 20 b では $155.3 \mathrm{~Hz}$, 21 は $189.3 \mathrm{~Hz}$ であり, 関連する 4 配位ジシランより, かなり大きい值を示した。これらの事実はシリルシリ カートの Si-Si 結合の特異性を示していて興味深い。

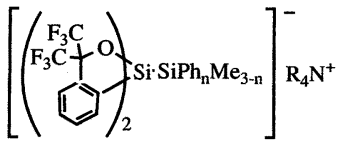

20a, $\mathrm{n}=3, \mathbf{R}=\mathrm{Et}$ 20b, $\mathrm{n}=2, \mathrm{R}=\mathrm{n}-\mathrm{Bu}$

\section{5. 有機シリカートの炭素-ケイ素結合の 酸化的切断}

有機ケイ素化合物の炭素-ケイ素結合の酸化的切断は 様々な方法で実行可能であり, 重要な有機合成反応の 1 つとなっている ${ }^{2 \mathrm{~d}, 31)}$ 。この際にも高配位ケイ素中間体の
介在が示唆されている。先に, アルキルシラン類の炭 素-ケイ素結合がトリメチルアミン-N-オキシドによっ て切断されることが見いだされているが321，この際， $\mathrm{DMF}$ 中, $70 \sim 140^{\circ} \mathrm{C}$ のようなやや過酷な条件が必要と された。しかし，アルキルおよびアリールトリフルオロ シランを用いると, 表 15 に示すようにクロロホル ム-THF 混合溶媒中, 室温できわめて容易に炭素-ケイ 素結合の切断が起こり, 対応するアルコールを生成し た ${ }^{33)}$ 。

Table 15 Reaction of organotrifluorosilanes with trimethylamine- $\mathrm{N}$-oxide in $\mathrm{THF} / \mathrm{CHCl}_{3}$.

\begin{tabular}{|c|c|c|}
\hline$\frac{\mathrm{Me}_{3} \mathrm{~N}^{+}-\mathrm{O}}{\mathrm{THF} / \mathrm{CHC}}$ & $\underset{\mathrm{I}_{3}}{\longrightarrow}-\mathrm{ROSiF}_{3} \mid \stackrel{\mathrm{H}_{2} \mathrm{C}}{\longrightarrow}$ & ROH \\
\hline Trifluorosilane & Reaction Conditions & $\begin{array}{c}\text { Yield/\% of } \\
\text { Alcohol }\end{array}$ \\
\hline \multirow{2}{*}{$\begin{array}{l}\mathrm{PhSiF}_{3} \\
\mathrm{PhCH}_{2} \mathrm{SiF}_{3}\end{array}$} & $\mathrm{rt}, 12 \mathrm{~h}$ & 80 \\
\hline & $\mathrm{rt}, 12 \mathrm{~h}$ & 98 \\
\hline \multirow{2}{*}{$\begin{array}{l}\mathrm{CH}_{3}\left(\mathrm{CH}_{2}\right)_{7} \mathrm{SiF}_{3} \\
\text { exo-Norbornyl-SiF } \\
2 \mathrm{~d}(\mathrm{E} / \mathrm{Z}=97 / 3)\end{array}$} & $\begin{array}{l}\text { rt, } 50 \mathrm{~h} \\
\mathrm{rt}, 16 \mathrm{~h}\end{array}$ & $\begin{array}{l}94 \\
89 \mathrm{~b}\end{array}$ \\
\hline & $\mathrm{rt}, 20 \mathrm{~h}$ & $83(96 / 4)$ \\
\hline $2 d(E / Z=5 / 95)$ & $\mathrm{rt}, 20 \mathrm{~h}$ & $85(6 / 94)$ \\
\hline
\end{tabular}

a. Exo/endo $=100 / 0$ b. Exo/endo $=100 / 0$. c. $E / Z$ ratio is shown in parentheses.

玉尾らはアルキルシランの過酸化水素等による切断に 対して 6 配位中間体を経由する機構を提唱している が311，本反応では，下に示す 5 配位シリカート中間体か ら, 有機基の酸素上への移動とトリメチルアミンの脱離 が協奏的に起こる機構が推定された。

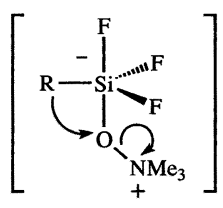

6. おわりに

高配位ケイ素化学の特徴の発見と応用の研究は現在も 継続中であり，高配位ケイ素化合物のこれまで知られて いなかった興味深い反応挙動が明らかになりつつある。 これらについてはいずれ稿を改めて報告したい。

本研究は東北大学理学部にて櫻井英樹教授とともに, 佐藤一彦, 小林峰生, 日野賢一, 上田 亨, 関本和志の 学生諸氏, ドイッより留学された R. Gewald 博士の協 力を得てなされたものである。特に現名古屋大学理学部 助手の佐藤一彦博士はその中心的役割を果たした。また, 理論計算に際して(株)日立製作所生産技術研究所の牛田 二郎, 羽田雅彦, 伊沢 勝 3 博士のご協力を得た。記し 
て, 感謝の意を表したい。

本稿執筆中に, 熊田 誠先生(京都大学名誉教授) と櫻 井英樹先生 (東北大学教授)のお二人に学士院恩賜賞が授 与されるとの嬉しいニュースを聞いた。櫻井英樹先生か らは長年にわたりご薰陶を受け，先生がこれまで日本の 有機ケイ素化学をリードされた今日の隆盛を築かれた永 い道程を目の当たりにしてきたので, 感慨無量のものが ある。

お二人のご栄誉は次代を担うものにとって大いなる励 みである。今後の有機ケイ素化学のますますの発展を祈 り,この小論文を両先生に捧げる。

(平成 6 年 3 月 25 日受理)

\section{文献}

1) 高配位ケイ素化学一般：(a) R.J.P. Corriu, C. Guérin, J.J.E. Moreau, Top. Stereochem., 15, 43 (1984); (b) R.J.P. Corriu, J.C. Young, "The Chemistry of Organic Silicon Compounds"; eds. by S. Patai, Z. Rappoport, John Wily, Chichester, 1989, Part 2, Chapter 20

2) 有機合成への応用: (a) H. Sakurai, “Selectivities in Lewis Acid Promoted Reactions", ed. by D. Schinzer, Kluwer, Dordrecht, 1989, p.203; (b) idem, Symlett, 1989, 1; (c) idem, "Chemistry and Technology of Silicon and Tin", eds. by V.G. Kumar Das, N.S. Weng, M. Gielen, Oxford University Press, Oxford, 1992, p.53; (d) H. Sakurai, "New Aspects of Organic Chemistry II", eds. by Z. Yoshida, Y. Ohshiro, Kodansha, Tokyo, 1992, p.129; (e) 玉尾皓平, 吉田潤一, 熊田 誠, 有合化, 38, 769 (1980); (f) 玉尾皓平, 有合化, 46, 861 (1988); (g) 細見 彰, 高良真也, 富永義 則, 有合化, 47, 831 (1989); (h) Y. Hatanaka, T. Hiyama, Synlett, 1991, 845; (i) C. Chuit, R.J.P. Corriu, C. Reye, J.C. Young, Chem. Rev., 93, 1371 (1933); (j) M. Kira, "Advanced Molecular Conversion”, ed. by N. Sonoda, MYU, Tokyo, 1991, p.179

3) 総説: (a) H. Sakurai, Pure Appl. Chem., 54, 1 (1982); (b) idem, ibid., 57, 1759 (1985); (c) 細 見 彰, 櫻井英樹, 有合化, 43, 406 (1985); (d) A. Hosomi, Acc. Chem. Res., 21, 200 (1988)

4) (a) A. Hosomi, S. Kohra, Y. Tominaga, J. Chem. Soc., Chem. Commun., 1987, 1517; (b) idem, Chem. Pharm. Bull., 35, 2155 (1987); (c) T. Hayashi, Y. Matsuoka, T. Kiyoi, Y. Ito, S. Kohra, Y. Tominaga, A. Hosomi, Tetrahedron Lett., 29, 5667 (1988) (d) G. Cerveau, C. Chuit, R.J.P. Corriu, C. Reye, J. Organomet. Chem., 328, C 17 (1987)
5) A. Hosomi, A. Shirahata, H. Sakurai, Tetrahedron Lett., 1978, 4043

6) (a) G. Majetich, A.M. Casares, D. Chapman, M. Behnke, Tetrahedron Lett., 24, 1909 (1983); (b) idem, J. Org. Chem . 51, 1745 (1986); (c) G. Majetich, R.W. Desmond, Jr., J.J. Soria, ibid., 51, $1753(1986)$

7) 小林峰生, 未発表デー夕

8) M. Kira, M. Kobayashi, H. Sakurai, Tetrahedron Lett., 28, 4081 (1987)

9) M. Kira, K. Sato, H. Sakurai, J. Am. Chem. Soc., 110,4599 (1988)

10) R.W. Hoffman, H.J. Zeiss, J. Org. Chem., 46, 1309 (1981)

11) (a) N. Furuya, T. Sukawa, J. Organomet. Chem., 96, C1 (1975); (b) J. Tsuji, M. Hara, K. Ohno, Tetrahedron, 30, 2143 (1974)

12) M. Kira, T. Hino, H. Sakurai, Tetrahedron Lett., 30, 1099 (1989)

13) (a) M. Kira, K. Sato, H. Sakurai, J. Am. Chem.Soc., 112, 257 (1990); (b) R. Gewald, 未 発表デー夕

14) S. Kobayashi, K. Nishino, Tetrahedron Lett., 34, 3453 (1993)

15）吉良満夫, 化学と工業, 43, 614 (1990)

16) M. Kira, K. Sato, H. Sakurai, M. Hada, M. Izawa, J. Ushio, Chem. Lett., 1991, 387

17) Y. Li, K.N. Houk, J. Am. Chem. Soc., 111, 1236 (1989)

18) K. Sato, M. Kira, H. Sakurai, ibid., 111, 6429 (1989)

19）K. Sato, K. Sekimoto, R. Gewald，未発表デー夕

20) M. Kira, T. Hino, H. Sakurai, Chem. Lett., 1991 , 277

21) (a) J. Boyer, R.J.P. Corriu, R. Perz, C. Reye, Tetrahedron, 37, 2165 (1981); (b) J. Boyer, R.J.P. Corriu, R. Perz, M. Poirier, C. Reye, Synthesis, 1981, 558; (c) C. Chuit, R.J.P. Corriu, R. Perz, C. Reye, ibid., 1982, 981

22) (a) M. Fujita, T. Hiyama, J. Am. Chem. Soc., 106, 4629 (1984); (b) idem, ibid., 107, 8294 (1985); (c) idem, Tetrahedron Lett., 28, 2263 (1986)

23) (a) A. Hosomi, H. Hayashida, S. Kohra, Y. Tominaga, J. Chem. Soc., Chem. Commun., 1986, 1411; (b) S. Kohra, H. Hayashida, Y. Tominaga, A. Hosomi, Tetrahedron Lett., 29, 959 (1988); (c) Y. Tominaga, Y. Matsuoka, H. Hayashida, S. Kohra, A. Hosomi, ibid., 29, 5771

24) M. Kira, K. Sato, H. Sakurai, J. Org. Chem ., 52, 948 (1987)

25) idem, Chem. Lett., 1987, 2243

26) (a) E.F. Perozzi, J.C. Martin, J. Am. Chem. 
Soc., 101, 1591 (1981); (b) S .K. Chopra, J.C. Martin, ibid., 112, 5342 (1990)

27) E.R.H. Walker, Chem. Soc. Rev., 1976, 23

28) (a) H. Sakurai, A. Okada, M. Kira, K. Yonezawa, Tetrahedron Lett., 1971, 1511; (b) H. Sakurai, F. Kondo, J. Organomet. Chem., 92, C 46 (1975); (c) H. Watanabe, K. Higuchi, M. Kobayashi, M. Hara, Y. Koike, T. Kitahara, Y. Nagai, J. Chem. Soc., Chem. Commun., 1977, 534; (d) T. Hiyama, M. Obayashi, I. Mori, H. Nozaki, J. Org. Chem.,
48, $912(1983)$

29) M.S. Gordon, L.P. Davis, L.W. Burggraf, R. Damraur, J. Am. Chem. Soc., 108, 7889 (1986)

30) M. Kira, K. Sato, H. Sakurai, ibid., 111, 3747 (1989)

31）玉尾皓平，林 高史，伊藤嘉彦，日化，1990，509

32) H. Sakurai, M. Ando, N. Kawada, K. Sato, A. Hosomi, Tetrahedron Lett., 27, 75 (1986)

33) M. Kira, K. Sato, H. Sakurai, ibid., 30, 4375 (1989)

\section{第 52 巻第 7 号予定}

\section{巻 頭 言}

創薬研究とセレンディピテ

総説および総合論文

キノカルシンの全合成

大環状ホスト化合物を用いる糖の分子認識……

ジクロロカルベンと低配位リン化合物の反応

不斉記憶.

軌道非対称化による $\pi$ 反応面選択

Alkyne- $\mathrm{Co}_{2}(\mathrm{CO})_{6}$ 錯体を用いる高立体選択的反応の開発

\section{ケミカルス覚え書き}

水素化アルミニウムリチウムおよび水素化アルミニウムナトリウム

十字路

錯形成誘起シフト|

コットン効果

結合状態の表記法 $\lambda, \delta, \eta$

Pauson-Khand 反応.

REVINDEX，新しい合成ほか
藤野 政彦

加藤 正 ら

青山 安宏ら

豊田 耕三ら 川端 猛夫ら 大和田智彦ら ·向智里ら 橋本 眞一 青山 安宏 豊田 耕三 向智里 